\title{
Seriation Proposed by Kleinschmidt (1982: Table 19) of Allen Phase and Frankston Phase Sites in the Upper Neches River
}

Timothy K. Perttula

Heritage Research Center, Stephen F. Austin State University

Follow this and additional works at: https://scholarworks.sfasu.edu/ita

Part of the American Material Culture Commons, Archaeological Anthropology Commons, Environmental Studies Commons, Other American Studies Commons, Other Arts and Humanities Commons, Other History of Art, Architecture, and Archaeology Commons, and the United States History Commons

Tell us how this article helped you.

This Article is brought to you for free and open access by the Center for Regional Heritage Research at SFA ScholarWorks. It has been accepted for inclusion in Index of Texas Archaeology: Open Access Gray Literature from the Lone Star State by an authorized editor of SFA ScholarWorks. For more information, please contact cdsscholarworks@sfasu.edu. 
Seriation Proposed by Kleinschmidt (1982: Table 19) of Allen Phase and Frankston Phase Sites in the Upper Neches River

\section{Creative Commons License}

(c) (1) (8)

This work is licensed under a Creative Commons Attribution-NonCommercial 4.0 International License 


\section{SERIATION PROPOSED BY KLEINSCHMIDT (1982: Table 19) OF ALLEN PHASE AND FRANKSTON PHASE SITES IN THE UPPER NECHES RIVER BASIN}

\section{Timothy K. Perttula}

Klcinschmidt (1982) reviewed sherd and vessel collections from a number of Frankston phase (ca. A.D. 1400-1650) and Allen phase (ca. A.D. 1650-1800+) sites in the upper Neches River basin (Anderson, Cherokee, Henderson, and Smith counties) and developed a ceramic frequency seriation (sce O'Brien and Lyman 1999) of those sites morc than 25 years ago (Kleinschmidt 1982: Table 19). That scriation is still useful today, or at least I find it so, because it does seem to provide a good measure of temporal changes in the kinds of dccorated ceramic vessels used by these Caddo peoples, as wcll as a good measure of the direction of changes in ceramic decorative styles.

For my purposes here, other than reintroducing Kleinschmidt's (1982) work to those that may not be familiar with it, 1 focus on temporal changes in the engraved fine ware vessels as seen in that seriation. The fine wares in question are Poynor Engraved (PO), Patton Engraved, Hume Engraved, and a variety of Poynor Engraved (PP) that shared stylistic elements with Patton Engraved vessels (Figure 1 and 2). In broad strokes, Kleinschmidt (1982) recognizes three sub-phases of the Frankston phase, beginning with the Frankston 1 sub-phase and ending with the Frankston 3 sub-phase, followed by the Allen phase (Table 1). In the earliest part of the Frankston phase, Poynor Engraved (PO variety) is the exclusive fine ware ceramic. Through time, the PP variety of Poynor Engraved, Patton Engraved, and Hume Engraved make their appearance and become more popular, at the expense of the PO variety of Poynor Engraved.

Table 1. Seriation of Engraved Ceramics in Frankston and Allen phase sites, based on Kleinschmidt (1982: Table 19).

$\begin{array}{llll}\text { Phase } & \begin{array}{l}\text { Poynor (PO) } \\ \text { Engraved }\end{array} & \begin{array}{l}\text { Poynor (PP) } \\ \text { Engraved }\end{array} & \begin{array}{l}\text { Patton Hume } \\ \text { Engr. Engraved }\end{array}\end{array} \quad$ N of vessels

A.D. $1400 / 1450-1650$

$\begin{array}{llllll}\text { Frankston 1 } & 100.0^{*} & 0.0 & 0.0 & 0.0 & 39 \\ \text { Frankston 2 } & 80.0 & 7.2 & 7.2 & 5.8 & 139 \\ \text { Frankston 3 } & 46.3 & 23.9 & 22.4 & 7.5 & 67\end{array}$

A.D. $1650-1800+$

$\begin{array}{llllll}\text { Allen } & 6.6 & 21.1 & 59.2 & 13.2 & 76\end{array}$

*pcrcentage; total vessels for all assemblages $(n=321)$

+ the ending datc of the Allen phase has not bcen established through archaeological means.

Certainly a case can be made that the Allen phase continues until the late 1830 s, when the Hasinai Caddo were removed from East Texas 


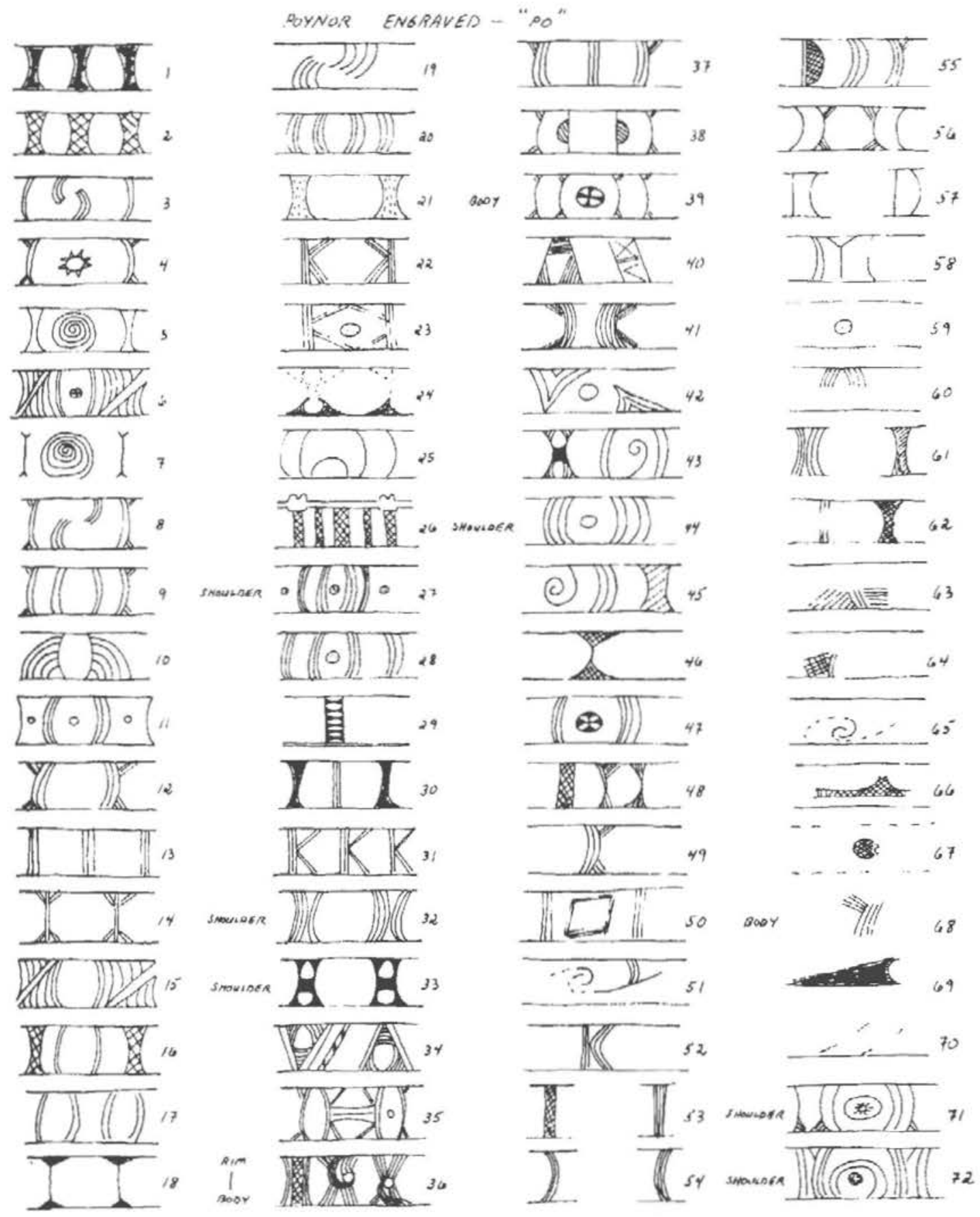

Figure 1. Poynor Engraved (PO variety). 


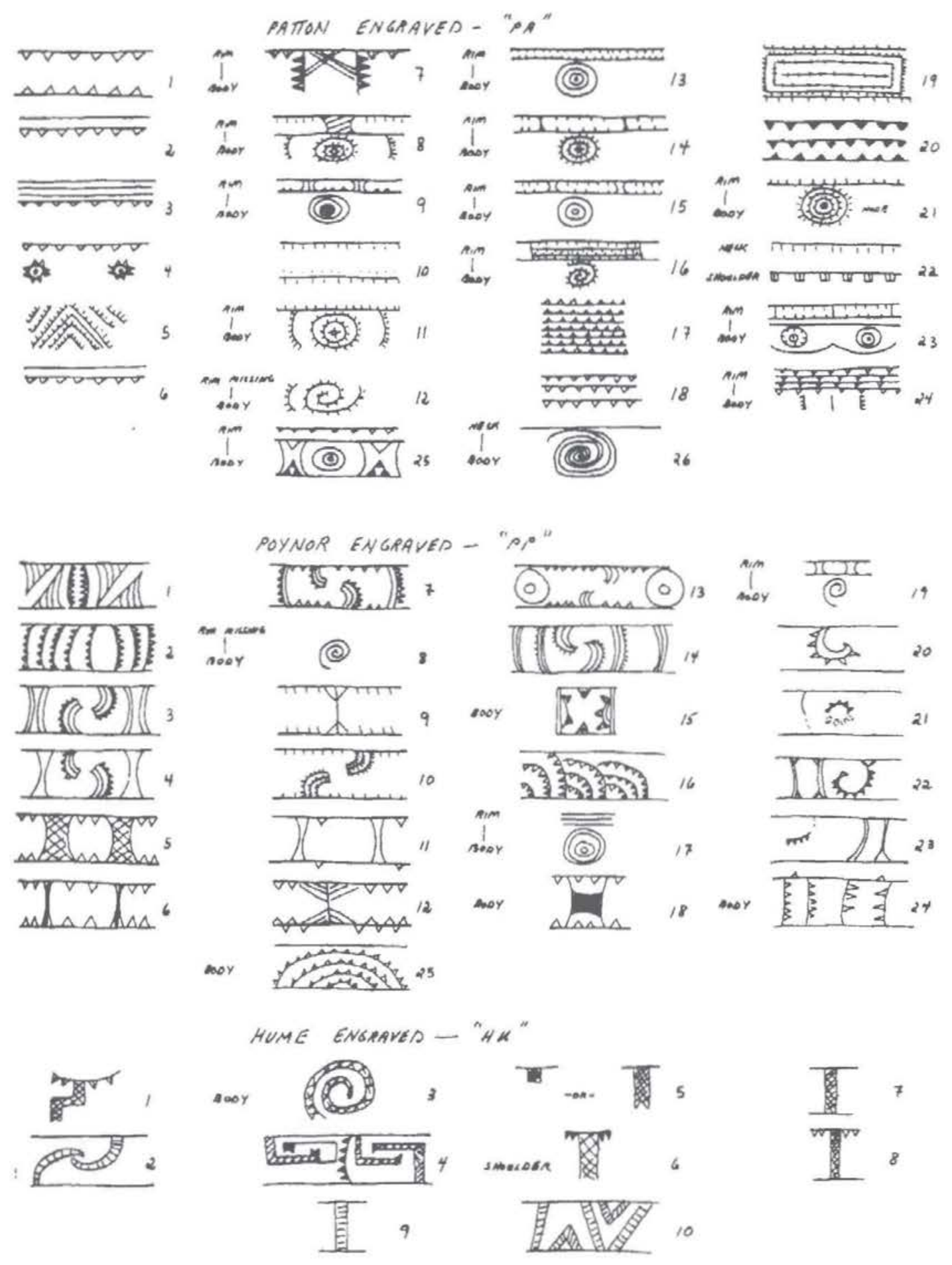

Figure 2. Poynor Engraved (PP variety), Patton Engraved, and Hume Engraved. 
By the end of the Frankston phase (sub-phase 3), the PO variety of Poynor Engraved only accounts for $46 \%$ of the engraved fine wares, with considerable numbers of Poynor Engraved (PP variety), Patton Engraved, and Hume Engraved vessels (see Table 1). Nevertheless, during all three sub-phases of the Frankston phase, Poynor Engraved vessels account for between $70.2-100 \%$ of the total number of sub-phase vessels.

During the later Allen phase, both varieties of Poynor Engraved account for only $27.7 \%$ of the vessels in the seriation. There is a dramatic increase in the popularity of Patton Engraved fine wares-59\%--almost a three-fold increase from the Frankston 3 sub-phase. Kleinschmidt's seriation further indicates that Hume Engraved vessels also appear to become more common from the time of the Frankston phase to the post-A.D. 1650 Allen phase (see Table 1).

\section{References Cited}

Kleinschmidt, U. K. W.

1982 Review and Analysis of the A. C. Saunders Site, 41AN19, Anderson County, Texas. Master's thesis, Department of Anthropology, The University of Texas at Austin.

O'Brien, M. J. and R. L. Lyman

1999 Seriation, Stratigraphy, and Index Fossils: The Backbone of Archaeological Dating. Kluwer Academic/Plenum Publishers, New York. 